would lead to failure of suppression of HOXB-8 expression in the anterior limb field. Ectopic expression of HOXB-8 would then specify cells in the anterior limb field as $Z P A$, leading to partial or complete duplication of zeugopod, autopod, and stylopod.

There are no reports of zeugopod (humerus/femur) duplication in Laurin-Sandrow syndrome, which would argue against the above hypothesis. To my knowledge, however, no author has to date thoroughly examined the humeri and femora of LaurinSandrow patients for any evidence of abnormal patterning. ${ }^{711}$ Further delineation of the Laurin-Sandrow phenotype, especially with regard to more proximal skeletal elements, would be most helpful in the search for candidate genes for this intriguing syndrome.

$M$ A M VAN STEENSEL Department of Human Genetics, University Hospital Nijmegen, Geert Grooteplein 10, 6500 HB Nijmegen, The Netherlands

1 Hatchwell E, Dennis N. Mirror hands and feet a further case of Laurin-Sandrow syndrome. $\mathscr{f}$ Med Genet 1996;33:426-8.

2 Charité J, De Graaff W, Shen S, Deschamps J. Ectopic expression of Hoxb-8 causes duplication of the ZPA in the forelimb and homeotic transformation of axial structures. Cell 1994 78:589-601.

3 Pollock RA, Sreenath T, Ngo L, Bieberich CJ Gain of function mutations for paralogous $\mathrm{Hox}$ gene function. Proc Natl Acad Sci USA 1995;92:4492-6.

4 Forsthoefel PF. Genetics and manifold effects of Strong's luxoid gene in the mouse, including its Strong's luxoid gene in the mouse, including its interactions with Green's luxoid and Car

luxate genes. F Morphol 1962;110:391-420. tylous limbs in Strong's luxoid mice result from tylous limbs in Strong's luxoid mice result from ectopic polaris

6 Sordino P, Van der Hoeven F, Duboule D. Hox gene expression in teleost fins and the origin of vertebrate digits. Nature 1995;375:678-81.

7 Kogekar N, Teebi AS, Vockley J. Sandrow syndrome of mirror hands and feet and facia abnormalities. Am F Med Genet 1993;46:126-8

8 Laurin CA, Favreau JC, Labelle P. Bilatera absence of the radius and tibia with bilatera reduplication of the ulna and fibula: a case report. $\mathcal{F}$ Bone foint Surg Am 1964;46:137-42.

9 Martin RA, Jones MC, Jones KL. Mirror hands and feet with a distinct nasal defect, an autosomal dominant condition. $\mathrm{Am} 尹 \mathrm{Med}$ Genet 1993;46:129-31.

10 Martinez-Frias ML, Alcaraz $M$, Espejo $P$ Gomez MA, Garcia de Leon R, Gonzalez Moro L. Laurin-Sandrow syndrome (mirror Moro $L$. Laurin-Sandrow syndrome (mirror hands and feet and nasal defects): description

11 Sandrow RE, Sullivan PD, Steel HH. Hereditary ulnar and fibular dimelia with peculiar facies: a case report. $\mathcal{F}$ Bone foint Surg Am 1970;52:367-70.

\section{A study of brothers with Klinefelter syndrome}

Klinefelter $e t a^{1}$ described males with infertility, hypogonadism, and gynaecomastia in 1942. The other clinical features of Klinefelter syndrome are now well delineated but not present in all affected subjects. ${ }^{2}$ The live birth prevalence of Klinefelter syndrome is approximately 1 in $1000 .^{3}$ The diagnosis is made and confirmed by the cytogenetic finding of $47, \mathrm{XXY}$. Klinefelter syndrome is considered to be a sporadic disorder resulting from non-disjunction. This is maternal in one half of cases and paternal in the remainder. ${ }^{4}$ The empirical recurrence risk is negligible as the condition occurs sporadically, with the recurrence risk equal to the birth prevalence, that is, 1 in 1000 . Given this, it is not surprising that Klinefelter syndrome is very rarely reported to recur within a family. There are limited reports of sibs with Klinefelter syndrome ${ }^{67}$ or of twins. ${ }^{8}{ }^{9}$ Therefore we wish to document our clinical, cytogenetic, and molecular findings of a family in which brothers had Klinefelter syndrome.

The older boy was diagnosed as having Klinefelter syndrome at the age of 5 years. $\mathrm{He}$ had reduced left elbow supination and radiography showed radioulnar synostosis. Diagnosis was made in the younger sib at the age of 3 years because of undescended testes and a "willowy appearance" similar to his older affected brother. Both had heights approximately on the 50th centile, weights on the 3 rd centile, and reduced upper to lower body segment ratios of 0.87 and 0.85 . The older sib is at Tanner stage 1 of sexual development at 11 years. Both are otherwise normal on examination, of normal intellectual ability, and neither has any behavioural problems.

Both parents were healthy, normal on examination, and aged 24 years at the time of birth of their first child with Klinefelter syndrome. The couple had no difficulty in conceiving and no recognised pregnancy losses. They are first cousins from the Punjab and are themselves products of first cousin marriages (fig 1). There are no other family members known to have chromosome anomalies, infertility, or frequent miscarriages.

Chromosome analysis of peripheral blood lymphocytes was performed on nuclear family members, 50 cells being examined in each case. The brothers with Klinefelter syndrome were non-mosaic $47, \mathrm{XXY}$, other family members having normal results. $\mathrm{X}$ chromosome haplotype analysis was performed using an Applied Biosystems 373 DNA Sequencer and Genescan 672 software. The microsatellite present in intron 13 of the factor VIIIC gene at Xq28 was informative, but nine microsatellites from the dystrophin gene were uninformative. ${ }^{10}$ The results are shown in fig

1; both boys with Klinefelter syndrome had

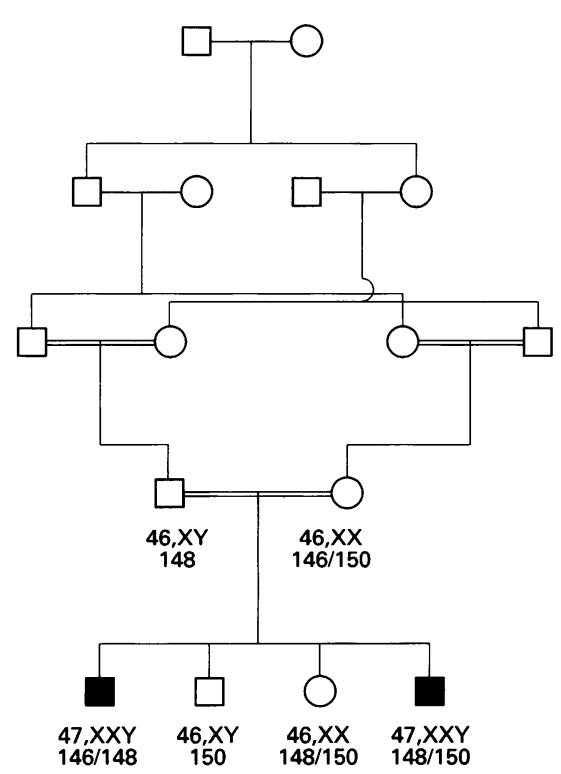

Figure 1 Pedigree with the males with Klinefelter syndrome shown as filled squares. Cytogenetic analyses and $X$ chromosome genotype results are shown for the nuclear family. The latter were generated using the microsatellite present in intron 13 of the factor VIIIC gene. The results are given as the polymerase chain reaction products measured in base pairs. apparently inherited an X chromosome from their father.

These sibs with Klinefelter syndrome had typical clinical features, non-mosaic 47,XXY, and their additional $X$ chromosome was the result of a paternal meiosis I error. Possible explanations for this situation are chance, that the father is a Klinefelter syndrome mosaic which seems unlikely, or that the father has an autosomal recessive disorder affecting meiosis. We have been unable to investigate the family further by single sperm analysis and because no other relative is known to have had a child with aneuploidy.

C GEOFFREY WOODS

Yorkshire Regional Genetics Service, Department of Clinical Genetics, Ashley Wing, St fames's University Hospital, Beckett Street, Leeds LS9 7TF, UK

JAYNE NOBLE

Regional DNA Laboratory, Department of Clinical Genetics, Ashley Wing, St fames's University Hospital, Beckett Street, Leeds LS9 7TF, UK

ALAISTER R FALCONER

Department of Paediatrics, Scarborough General Hospital, Woodlands Drive, Scarborough, North Yorkshire YO12 6QL, UK

1 Klinefelter HF, Reifenstein EC, Albright F, et al. Syndrome characterised by gynaecomastia, aspermatogenesis without aleydigism and in creased secretion of follicle stimulating hormone. $₹$ Clin Endocrinol Metab 1942;2:615.

2 Jones KJ. Smith's recognisable patterns of human malformation. 4th ed. Philadelphia: Saunders, 1988.

3 Nielsen J, Wohlert $M$. Sex chromosome abnormalities found among 34,910 newborn children: results from a 13-year incidence study in Arhus, Denmark. Birth Defects 1990;26:20923.

4 Jacobs PA, Hassold TJ, Whittington E, et al. Klinefelter's syndrome: an analysis of the origin of the additional sex chromosome using molecular probes. Ann Hum Genet 1988;52:93109.

5 Lorda-Sanchez I, Binkert F, Maechler M, Robinson WP, Schinzel AA. Reduced recombination and paternal age effect in Klinefelter syndrome. Hum Genet 1992;89:524-30.

6 Gustavson KH, Gamstorp I, Meurling S. Bilateral teratoma of testis in two brothers with eral teratoma of testis in two brothers with 47,XXY K

7 Takayasy J, Kinoshita K, Tsuboi T, Kurihara T. Twins with Klinefelter's syndrome. Lance 1967;ii: 1424

8 Hatch TR, Moore RJ. Klinefelter syndrome in identical twins. Urology 1985;26:396-7.

9 Flannery DB, Brown JA, Redwine FO, Winter P, Nance WE. Antenatally detected Klinefelter's syndrome in twins. Acta Genet Med Gemellol 1984;33:51-6.

10 Laloz MR, McVey JH, Pattison JK, Tuddenham EG. Haemophilia A diagnosis by analysis of hypervariable dinucleotide repeats within
factor VIII gene. Lancet 1991;338:207-11.

\section{BOOK REVIEWS}

If you wish to order or require further information regarding the titles reviewed here, please write to or telephone the BMJ Bookshop, PO Box 295, London WC1H 9JR Tel 0171383 6244. Fax 01713836662 . Books are supplied post free in the UK and for BFPO addresses. Overseas customers should add $15 \%$ for postage and packing. Payment can be made by cheque in sterling drawn on a UK bank or by credit card (Mastercard, Visa, or American Express) stating card number, expiry date, and full name. (The price and availability are occasionally subject to revision by the Publishers.) 